\title{
Bedre rettigheter for syke barn
}

I september 2011 vedtok Europarådets helseministre en deklarasjon om barnevennlige helsetjenester. Den vil det være viktig å kjenne til for alle som har med helsetjenester for barn å gjøre, og den vil hvis den blir implementert - klart styrke barns og foreldres rettigheter, kanskje spesielt i svake stater.

Helseministre fra medlemslandene i Europarådet møtes jevnlig for å diskutere spørsmål av felles interesse. Det niende møtet fant sted i Lisboa i september 2011. Konferansen, med tittelen «Child-Friendly Health Care: Building a Healthy Future for and with Children», munnet ut i en deklarasjon som ble enstemmig vedtatt (1) (ramme 1). Deklarasjonen plasserer barnet i sentrum og fremmer barnets rett til å ha foreldrene (eller annen omsorgsperson) hos seg under hele sykehusoppholdet. Videre skal barnets mening og ønsker i økende grad tas hensyn til ved økende alder og modenhet.

I Norge har vel de fleste den holdning at dette er da selvsagte krav. Men man skal ikke langt tilbake $\mathrm{i}$ historien $\mathrm{i}$ vårt eget land før helsetjenestene for barn så ganske så annerledes ut. Førsteforfatter hadde sin første jobb på laboratoriet på Skarnes sykehus i 1958. Foreldre som kom med et sykt barn, ble stanset på dørstokken og fikk beskjed at de skulle få en telefon når de kunne hente barnet.
Forholdene forandret seg fort i 1960årene, og på barneavdelingene hadde foreldrene nokså fri adgang fra tidlig i 1970årene. Men noe lovverk rundt dette hadde vi ikke. Dette kom forst i 1988, og da som forskrifter (2). Disse forskriftene ble videreført og utvidet fra 1.1. 2001 med hjemmel i spesialisthelsetjenesteloven (3).

\section{For og med barn}

Menneskerettigheter har alltid vært viktigste saksområde for Europarådet, og barns

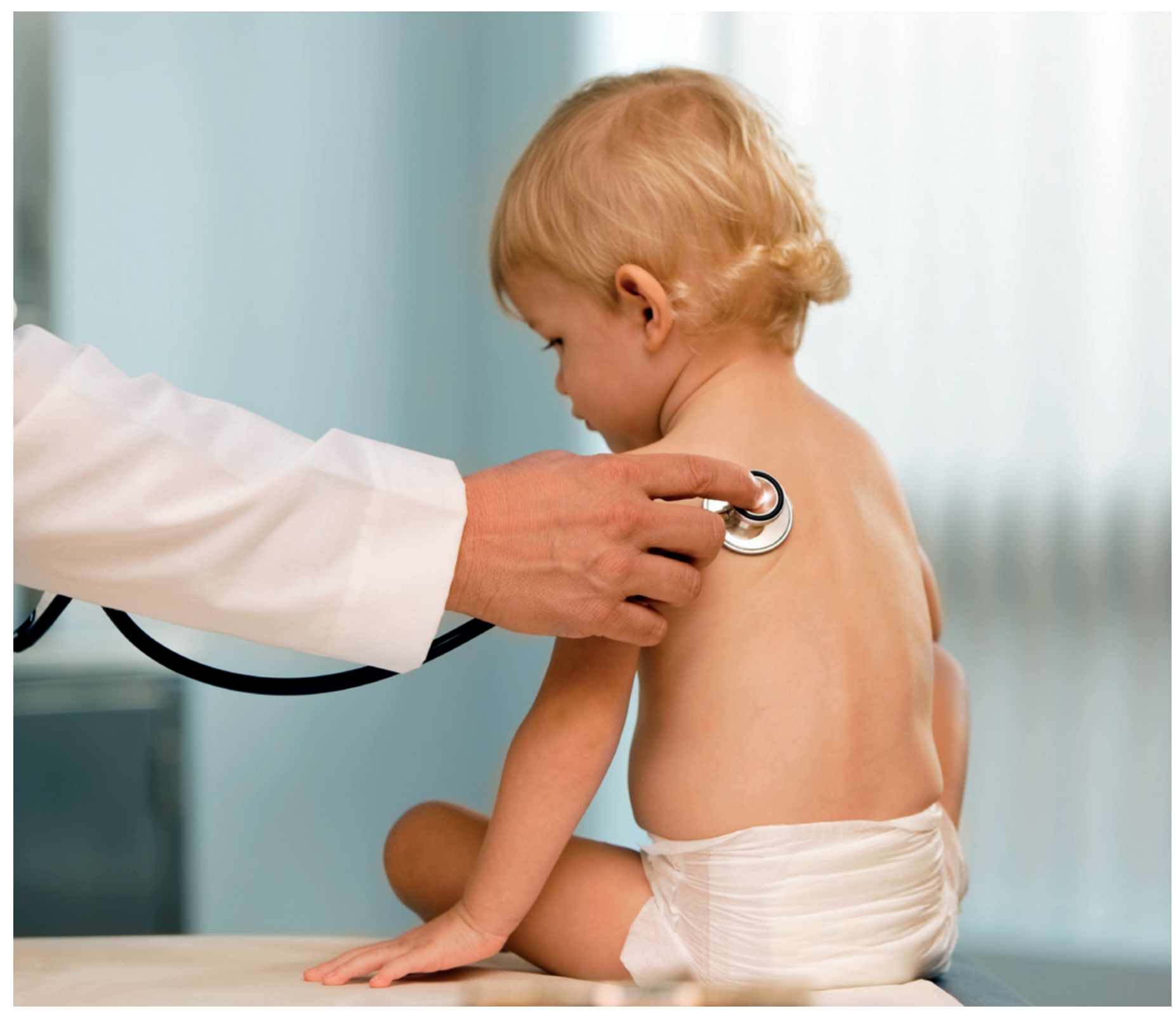




\section{Ramme 1}

Deklarasjonen om barnevennlige helsetjenester, vedtatt av Europarådets helsekomité i 2011, åpner slik (1):

We, the Ministers responsible for health in the 47 member states of the Council Of Europe, meeting at the $9^{\text {th }}$ Council of Europe Conference of Health Ministers in Lisbon on 29 to 30 September on the invitation of the Portugese Government,

\section{RECOGNIZING THAT}

Healthy children are the future of Europe and the rights of every child to equitable access to health care which is appropriate, child-oriented and of good quality must be respected;

The health and well-being of children are priority goals shared by all member states within the general context of human rights and the specific framework of children's rights;

Investments in children's health and wellbeing ensures better outcome for the entire lifespan and may reduce the burden on health and welfare systems, since a significant number of avoidable physical and socio-psychological problems in adult life have their origin in infancy and childhood

Effective and efficient child-friendly healthcare contributes to social cohesion rettigheter er blitt fremmet gjennom programmet «Building a Europe for and with Children». I 2009 nedsatte helsekomiteen i Europarådet, hvor OCR er formann, en ekspertkomité for å se på barns rettigheter ved sykdom og innleggelse i sykehus. Ekspertkomiteen hadde 15 medlemmer fra 15 land, med SOL som norsk representant og nestleder i gruppen. Det var ekspertkomiteens innstilling som var grunnlagsdokumentet for deklarasjonsteksten.

Så må det være lov å stille spørsmålet om dette har vært et meningsfylt arbeid og om det vil ha noen effekt. Vårt svar er desidert ja til begge deler. Arbeidet i ekspertkomiteen har vært spennende og lærerikt - og ganske store forskjeller kom til syne. Europarådet har i dag 47 medlemsstater som samlet dekker det meste av Europa. I flere av landene blir barns rettigheter ikke tatt tilstrekkelig hensyn til.

Det gledelige siste avsnitt i deklarasjonen lyder: «The new strategy and Council of Europe action plan for social cohesion and the 2012-2015 strategy of the «Building a Europe for and with Children Programme» integrate the child-friendly health Care Approach.»

Dette velger vi å tolke som at vår utredning vil bli et aktivt og levende dokument i de nærmeste årene.

Sverre 0. Lie

sli@helsedir.no

Otto Christian Rø

Helsedirektoratet
Sverre O. Lie (f. 1938) er seniorrådgiver i global helse i Helsedirektoratet. Han er tidligere klinikksjef og professor ved Barneklinikken, Rikshospitalet.

Ingen oppgitte interessekonflikter.

Otto Christian Rø (f. 1946) er avdelingsdirektør for Avdeling utdanning og personell, Helsedirektoratet.

Ingen oppgitte interessekonflikter.

\section{Litteratur}

1. Child-friendly health care: building a healthy future for and with children. Final declaration. Council of Europe Health Ministers Conference, 29.9.2011. www.coelisbon2011.org. (10.1.2012).

2. Forskrift om barns opphold i helseinstitusjon. FOR 2000-12-01 nr 1217. www.lovdata.no/cgi-wift/ Idles?doc=/sf/sf/sf-20001201-1217.html (19.12.2011).

3. Lov om spesialisthelsetjenesten m.m. (spesialisthelsetjenesteloven). LOV 1999-07-02 nr 61. www.lovdata.no/all/hl-19990702-061.html (19.12.2011).

Mottatt 5.12. 2011, første revisjon innsendt 9.1. 2012, godkjent 12.1. 2012. Medisinsk redaktør Siri Lunde. 